\title{
Planning Educational Content in School Curriculum Documents: Examples of current practice from pre-schools in the Czech Republic and Slovakia
}

\author{
Eva Koželuhová, Barbora Loudová Stralczynská, \\ Milena Lipnická
}

\begin{abstract}
The aim of the research was to analyse the ways in which educational content is planned and taught in selected pre-school educational programmes in the Czech Republic and Slovakia, with a focus on the topics, educational objectives, and different approaches to school curriculum design.

Methods. The first part of the research consisted of a qualitative content analysis of the school educational programmes of 40 pre-schools in the Czech Republic and 40 reflective reports from the teachers of these pre-schools. The research focused on approaches to designing integrated educational blocks in these school educational programmes and on teachers 'preferences when implementing them in their teaching. The second part was undertaken in cooperation with the Faculty of Education of Matej Bel University in Banská Bystrica, Slovakia. Research data was obtained by a questionnaire survey among students of distance studies in study programmes preparing preschool teachers in the Czech Republic and Slovakia.

The results from the research sample indicated that the chronological approach of integrated educational blocks was the most popular type within pre-schools in both countries. The pre-schools designed the educational content according to the season and structured it into weekly themes. This approach might not necessarily fulfil the requirements of the Czech and Slovak national educational programmes in relation to the specified educational content according to the current needs and interests of children. Even though some teachers were often allowed to choose their own topics, the majority of teachers were still required to implement topics specified in the school educational programme. In conclusion, the paper provides a possible outline of the causes of this situation and suggests opportunities for further research.
\end{abstract}

Keywords: pre-school educational content, school educational programme, curriculum, planning 


\section{INTRODUCTION}

Czech and Slovak pre-school education developed together for many decades; however, since the early 1990s, they have developed in their own separate ways. During this period, the sharing of experiences and joint research work of academics from Czech and Slovak faculties of education has supported comparative studies in pre-school education and provided solutions to common problems. The authors have identified that during their teaching practice it is difficult for students to transform the educational content of their School Educational Programme (hereinafter SCHEP) into plans of educational activities at the classroom level. Planning the teaching of the educational content by teachers in training is often not based on the evaluation of children's educational needs and interests, but on fixed integrated educational blocks (hereinafter IBs) agreed in the SCHEP. IBs are set out in the school curriculum for certain periods of the school year and are specified for all classes of the pre-school. The Czech Framework Educational Programme for Pre-School Education (hereinafter FEP PE) and the Slovak State Educational Programme for Pre-Primary Education (hereinafter SEP) support child-centred education, i.e. creating an educational offer and adapting the content to the needs and interests of the children.

\section{Characteristics of SCHOOL EDUCATIONAL PROGRAMMES IN THE CZech Republic}

Pre-schools are required by FEP PE (2018) to create their own SCHEP, which is mandatory under the Education Act (Act No. 561/2004 Coll.). The school principal is responsible for its creation with input from all pedagogical staff (and other employees). FEP PE (2018) defines five educational areas, from which IBs are formed at the school level, on the basis of which teachers specify the educational offer at the class level. This gives pre-schools the freedom to design IBs in terms of content, scope, quantity, and timing, but they must also be flexible enough to allow teachers to choose what they will do with children in the classroom and match this to the interests and needs of the children. In this way, the teacher is granted the right to be responsible for the content of pre-school education. It is specified that the SCHEP should not contain too many IBs in order to avoid dilution of the educational content and the SCHEP states the intention and content of IBs, as well as the instructions for their implementation.

FEP PE (2018) does not specify any terms that would indicate when or how IBs should be implemented. Equally, theoretical sources are also silent on this matter (Svobodová, 2010; Šmelová \& Prášilová, 2018); they only describe possible options for implementation. Krejčová, Kargerová, and Syslová (2015) worked with the terms linear (chronological) or flexible in relation to the design of IBs. Other authors accept their terminology (Syslová et al., 2019; Průcha, 2016) to refer to the situation where IBs are implemented in a linear way according to the number of months of the school year (usually, each IB consists of four themes). On the other hand, a flexible 
design means that IBs are arranged parallel to each other and teachers use their educational content according to the needs of the children (Krejčová et al., 2015).

The research data indicated that these chronological and flexible approaches do not fully support the range of possibilities for pre-school teachers when designing IBs. As the national curriculum states, "integrated blocks connect their content with each other, complement each other, [and] they can penetrate and pass smoothly into one another" (FEP PE, 2018, p. 30). This means that teachers can combine multiple IBs simultaneously when choosing specific objectives and contents from more IBs and transform these into the educational content for a specific class. For the creation of the SCHEP, pre-school teachers have the use of a manual which provides them with flexibility for the preparation of the school (class) educational programme of the preschool (Smolíková, 2006).

\section{Characteristics OF SCHOOL EDUCATIONAL PROGRAMMES IN Slovakia}

The SCHEP is a fundamental document for schools, including pre-schools. It must be drawn up in accordance with the Education Act and with respect to the national educational programmes for each level of the education system (Education Act, 2008). The SCHEP enables preschools to use the educational standards from the national educational programme for pre-primary education as the basis for the school curriculum. In this way each pre-school creates its own SCHEP in accordance with its own local conditions and situation and based upon the traditions of pre-schools and matched to knowledge of the children, as well as the home environment they come from. There is no specified educational programme or methodological materials developed for any educational areas.

The pre-school can also create its own school curriculum, which should take account of the range of educational standards in accordance with the state educational programme. In the SCHEP the educational content is generally planned in the form of content units, similar to the IB in the Czech Republic. Teachers can adapt the educational content according to the needs and interests of children, as well as other conditions of the pre-school. It is important that the individual topics and sub-topics in the content unit are related to each other. "The individual units of content and the context of these and various topics are relatively similar to each other conceptually and have to create space for developing a knowledge system for infants and for establishing, developing, and reinforcing their skills, habits, attitudes. These content units should last for between two weeks and a quarter of the year" (Hajdúková et al., 2009, p. 32). The SCHEP is produced for a period of one educational cycle, which is normally three years, and the minimum period is one year. For the purposes of describing the research, we have kept the term 'integrated educational block' (IB), as it also 
corresponds to the Slovak concept of content units that integrates goals from all educational areas.

The aim of the research was to identify the ways in which educational content is planned in selected pre-school educational programmes and what opinions about the approaches to the design of the SCHEP predominate among students who already work as teachers in these pre-schools. Using data from Czech and Slovak students, we compared the current approaches to planning the educational content of SCHEPs in both countries.

Since becoming two independent nations at the beginning of 1993, they have been creating their own methods of improving pre-school education incorporating a child-centred approach. During the last two decades, different approaches to the design of the SCHEP have been a fundamental part of educational reform and so it is important to consider how teachers' methods of planning have evolved during the same period.

\section{Methods}

The research was designed as a qualitative-quantitative survey. The first part of the research was based upon the qualitative content analysis of school educational programmes and reflective reports from teachers of 40 pre-schools in the Czech Republic. The second part consisted of a questionnaire survey among 121 students of preschool pedagogy in cooperation with the Faculty of Education of
Matej Bel University in Banská Bystrica (hereinafter FE UMB).

When reviewing the characteristics of IBs, we use the term intention to indicate the educational objectives to prevent confusion between understanding the concept of intent and one of the levels of educational targets. The term intention can be understood as the target category, which includes the hierarchy of goals - framework targets, competencies, sub-goals, expected outputs. The concept of the topic is well understood by teachers, although the terminology for concepts associated with planning are used inconsistently. A 'thematic unit' is used (Svobodová, 2007; Smolíková, 2005), a 'class block' is used (Smolíková, 2006), a 'thematic part' is used (Syslová et al., 2019), a 'pedagogical project' is used (Burkovičová, 2008), etc. However, we have agreed to use the term 'topic'.

\section{Method of content analysis}

In the first part of the research, the intention was to obtain answers to the following research questions:

Q1 How are the integrated educational blocks of the SCHEP designed for planning classroom educational activities?

Q2 What are the intentions in the integrated educational blocks of the SCHEP?

Q3 What topics do the integrated educational blocks in the SCHEP contain?

Q4 What are the opinions of pre-school teachers on the design of integrated educational blocks in the SCHEP? 
For content analysis of the SCHEP, data was obtained from all second-year distance students of the Master's programme for Pedagogy of Pre-school Age at the Faculty of Education of Charles University in Prague (hereinafter FE UK). The students provided the SCHEP from the pre-schools where they worked. The content analysis of the SCHEPs was complemented by the content analysis of reflective reports of the students concerning different ways of designing and implementing IBs in their SCHEPs.

Inductive category creation was applied in the content analysis, which works with both a formative review of the reliability of categories in the middle of the analysis process and a summative review of reliability at the end of analysis. First, the individual parts of both types of document in the data sample were openly coded. The codes were created ad hoc, using the MAXQDA software. The individual codes were then grouped into categories, which were then analysed by thematic coding (Flick, 2006, in Švaříček \& Šedová, 2014). The categorisation of the codes was performed at the level of individual SCHEPs and the corresponding reflective reports from the teachers. Subsequently, the categories were compared and grouped according to selected criteria corresponding to particular research questions.

The categories in the analysis included: the explanation of IBs in terms of their implementation period, the design

Table 1 Research sample of content-analysed documents

\begin{tabular}{|l|c|l|}
\hline Document type & $\begin{array}{c}\text { Number of } \\
\text { documents analysed }\end{array}$ & $\begin{array}{l}\text { Method used for obtaining a research } \\
\text { sample of documents }\end{array}$ \\
\hline $\begin{array}{l}\text { SCHEPs from } \\
\text { pre-schools }\end{array}$ & 40 & $\begin{array}{l}\text { Electronic form of SCHEP from students' } \\
\text { pre-schools in the 2018/2019 and } \\
2019 / 2020 \text { academic years. }\end{array}$ \\
\hline $\begin{array}{l}\text { Written reflective reports } \\
\text { of students on the } \\
\text { pre-school of their }\end{array}$ & $\begin{array}{l}\text { Each student prepared a reflective report } \\
\text { evaluating the SCHEP of the pre-school in } \\
\text { which they worked as a teacher. The reports } \\
\text { ranged from one to three standard pages } \\
\text { of continuous text. The students evaluated } \\
\text { whether the SCHEP agreed with the guidelines } \\
\text { for creating a SCHEP formulated in the } \\
\text { Manual for Creating the SCHEP (Smolíková, } \\
\text { 2006) and discussed how satisfied they were } \\
\text { with the processing of the SCHEP from } \\
\text { the point of view of their own pedagogical } \\
\text { experience (conception, design, and } \\
\text { implementation of IB, educational topics). }\end{array}$ \\
\hline
\end{tabular}


and flexibility of their topics, their target focus, rigidity vs. flexibility within the IBs in relation to the work of teachers, selfevaluation, and student preferences. An overview of the categories was used in the evaluation of the results. To present the results, we used a graphical representation of the data to ensure the transparency of the evaluation (Miles \& Huberman, 1994). Finally, we performed a quantitative evaluation of the data related to the first research question, which we consider a useful complement to the qualitative conclusions (cf. Švaříček \& Šed’ová, 2014). The results of the analysis were communicated to the survey participants and this resulted in the validation of the results with the students and subsequently with colleagues from FE UK.

\section{Questionnaire method}

In the second part of the research, the questionnaire survey made it possible to obtain answers to the following research questions:

Table 2 Sample of students

\begin{tabular}{|c|c|c|c|c|c|c|}
\hline & \multicolumn{3}{|c|}{ Distance students at FE UK } & \multicolumn{3}{|c|}{ Distance students at FE UMB } \\
\hline & $\begin{array}{l}\text { Students } \\
\text { enrolled in } \\
\text { study pro- } \\
\text { gramme }\end{array}$ & $\begin{array}{c}\text { Frequency } \\
\text { in the ques- } \\
\text { tionnaire }\end{array}$ & $\begin{array}{l}\text { Expressed } \\
\% \text { ques- } \\
\text { tionnaire }\end{array}$ & $\begin{array}{l}\text { Students } \\
\text { enrolled in } \\
\text { study pro- } \\
\text { gramme }\end{array}$ & $\begin{array}{l}\text { Frequency } \\
\text { in the ques- } \\
\text { tionnaire }\end{array}$ & $\begin{array}{c}\text { Expressed } \\
\% \text { ques- } \\
\text { tionnaire }\end{array}$ \\
\hline $\begin{array}{l}\text { Bachelor's } \\
\text { study }\end{array}$ & \multicolumn{3}{|c|}{$\begin{array}{l}\text { Study programme: Teacher Training } \\
\text { for Pre-schools (Bc.) }\end{array}$} & \multicolumn{3}{|c|}{$\begin{array}{l}\text { Study programme: Pre-school } \\
\text { and elementary pedagogy (Bc.) }\end{array}$} \\
\hline $\begin{array}{l}\text { 1st year } \\
\text { of study }\end{array}$ & 23 & 23 & 35 & 41 & 15 & 27 \\
\hline 2nd year & 21 & 13 & 20 & 28 & 23 & 41 \\
\hline 3 rd year & 24 & 5 & 8 & 15 & 10 & 18 \\
\hline 4th year & - & - & - & 6 & - & - \\
\hline $\begin{array}{l}\text { Follow-up } \\
\text { Master's study }\end{array}$ & \multicolumn{3}{|c|}{$\begin{array}{c}\text { Study programme: Pedagogy } \\
\text { of Pre-school Age (Mgr.) }\end{array}$} & \multicolumn{3}{|c|}{$\begin{array}{l}\text { Study programme: Pre-school } \\
\text { pedagogy (Mgr.) }\end{array}$} \\
\hline $\begin{array}{l}\text { 1st year } \\
\text { of study }\end{array}$ & 18 & 9 & 14 & 4 & 3 & 5 \\
\hline 2nd year & 25 & 2 & 3 & 10 & 4 & 7 \\
\hline 3rd year & $31^{*}$ & 13 & 19 & 2 & 1 & 2 \\
\hline Together & 142 & 65 & 100 & 106 & 56 & 100 \\
\hline $\begin{array}{l}\text { Return on } \\
\text { questionnaires } \\
(\%)\end{array}$ & $46 \%$ & & & $53 \%$ & & \\
\hline
\end{tabular}

* The research at FE UK also included, in addition, students studying in 2019/2020 and also students of the second year of the Education of Pre-school Age Students degree programme in the year 2018/2019. 
Q5 What approach to designing integrated educational blocks is most common in SCHEPs and which do respondents prefer?

Q6 What ways of choosing topics do SCHEPs allow and which are most suitable for planning educational activities in the classroom?

Q7 For how long is it appropriate to design plans for educational activities in the classroom?

The respondents in the research sample all studied in distance programmes preparing pre-school teachers in the Bachelor's and Master's degree programmes in the 2019-2020 academic year at FE UK in Prague, Czech Republic and FE UMB in Banská Bystrica, Slovakia. The findings from the data obtained from both partner faculties were then compared.

When planning the survey, it was necessary to understand the school curricula in the two countries, compare the content, and use common terminology, so that the questionnaire could be understood by the Czech and Slovak respondents in the research sample.

The respondents also provided information about their current employment in pre-schools. $77 \%$ of the Czech respondents had a position as a teacher in a preschool, $8 \%$ were currently not working in a pre-school, and $12 \%$ held the position of an assistant teacher and 3\% were in the position of the head teacher in a preschool. The highest percentage of Slovak respondents in the research group was preschool teachers $(45 \%)$. On the contrary, $37 \%$ of the Slovak respondents stated that they did not currently work in any of the above positions in a pre-school. The remaining $18 \%$ mentioned other positions - assistant teacher in a pre-school (6\%), teacher in a primary school (4\%), assistant

Table 3 Length of students' pedagogical practice

\begin{tabular}{|l|c|c|c|c|}
\hline \multirow{2}{*}{$\begin{array}{l}\text { Length of pedagogical } \\
\text { practice, including maternity } \\
\text { and parental leave }\end{array}$} & \multicolumn{2}{|c|}{$\begin{array}{c}\text { Students from the research } \\
\text { group of FE UK (N=65) }\end{array}$} & \multicolumn{2}{c|}{$\begin{array}{c}\text { Students from the research } \\
\text { group of FE UMB (N=56) }\end{array}$} \\
\cline { 2 - 5 } & Frequency & $\begin{array}{c}\text { Expression } \\
(\mathbf{\%})\end{array}$ & Frequency & $\begin{array}{c}\text { Expression } \\
\text { (\%) }\end{array}$ \\
\hline up to 1 year & 11 & 17 & 13 & 23 \\
\hline 1 to 2 years & 20 & 31 & 5 & 9 \\
\hline 3 to 4 years & 13 & 20 & 12 & 21 \\
\hline 5 to 9 years & 9 & 14 & 8 & 14 \\
\hline 10 to 14 years & 6 & 9 & - & - \\
\hline 15 to 19 years & 3 & 5 & 1 & 2 \\
\hline 19 years and older & 2 & 3 & 1 & 29 \\
\hline no teaching experience & 1 & 2 & 16 & $\mathbf{1 0 0}$ \\
\hline Together & $\mathbf{6 5}$ & $\mathbf{1 0 0}$ & $\mathbf{5 6}$ & \\
\hline
\end{tabular}


teacher in a primary school (2\%), teacher in a primary art school (2\%), director of a pre-school (2\%), personal assistant (2\%).

The questionnaire consisted of 11 items, of which four contained data on the employment situation of the respondents in the two countries, the school curriculum and their current studies, the length of their teaching practice, and the position in which they work in the pre-school. The core of the questionnaire consisted of seven factual items. The questions were completed with a choice of answers (including the answer "other", with further specification). The respondents were also able to express their opinions in four open questions, related to specific differences in flexibility and any specific approach to the integrated planning of IBs and work with themes.

The questions were created in such a way that they enabled detection of the difference between the original form of the SCHEP and what the respondent's opinion was on whether it should be done differently. The data from the questionnaire was evaluated by statistical analysis of the data (determination of the frequency) and a statistical description was produced.

In the questionnaire survey, we chose basic terminology as we were only interested in the chronological and flexible type of IBs. The reason was clarity for the respondents; use of the term 'chronological' emphasised the time aspect of working with IBs and compliance with their time sequence. We also used the term 'flexible' because it includes the ability to disregard IBs freely according to the current needs of the teacher.

\section{Results}

\section{Results of the content analysis}

Research data is important for improving the quality of pre-school education; however, we are aware that it is not possible to generalise the results to the work of pre-schools in the Czech Republic and Slovakia in general. However, the research points to some problems in pedagogical practice which need to be analysed in more detail in future research.

\section{Planning IBs in SCHEPs for classroom educational activities}

From the beginning, the diversity of the individual SCHEPs of pre-schools was obvious, so we agreed to assess each SCHEP individually. The data analysis has shown that the terms chronological (linear) and flexible do not cover all the possibilities of how IBs were used within SCHEPs. For this reason, we have proposed three main categories of IB types for the data presentation. In addition to the terms chronological and flexible, which were used in the questionnaire survey, we identified the term transversal type of IB.

After creating a typology of the SCHEPs that were surveyed using the categories above (Table 4) we wondered how the chronological, flexible, and transversal types of IBs are represented when considering the different options teachers could use when planning educational activities (Figure 1). 
Table 4 Results of the content analysis of SCHEPs, i.e. the internal variability of the three main types of designing of IBs characterised by the main content categories

\begin{tabular}{|c|c|c|c|c|c|}
\hline 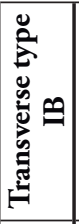 & $\begin{array}{l}\text { They are implemented } \\
\text { by selecting goals } \\
\text { across IBs, according } \\
\text { to the choice of the } \\
\text { teacher, and the blocks } \\
\text { are intertwined }\end{array}$ & 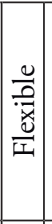 & Design of own topics & $\begin{array}{l}\text { Low support / high } \\
\text { freedom }\end{array}$ & 完 \\
\hline \multirow{4}{*}{ 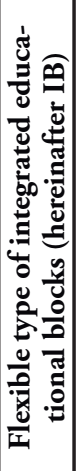 } & \multirow{4}{*}{$\begin{array}{l}\text { They are implemented in } \\
\text { the order determined by } \\
\text { the teacher; the blocks } \\
\text { combine general topics. } \\
\text { IBs are implemented } \\
\text { as a whole. The teacher } \\
\text { chooses the order of IBs } \\
\text { within the year, but the } \\
\text { IBs are set in the SCHEP; } \\
\text { the order of IBs is linear, } \\
\text { but with the flexibility of } \\
\text { including individual IBs } \\
\text { during the school year. }\end{array}$} & 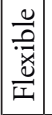 & Design of own topics & $\begin{array}{l}\text { Low support / high } \\
\text { freedom }\end{array}$ & \multirow{4}{*}{ 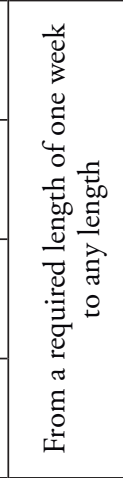 } \\
\hline & & \begin{tabular}{|l|}
$\frac{0}{0}$ \\
$: \frac{7}{x}$ \\
$\frac{0}{I}$ \\
\end{tabular} & $\begin{array}{l}\text { Possibility of choosing } \\
\text { topics from IB, or design- } \\
\text { ing your own }\end{array}$ & $\begin{array}{l}\text { Medium support / } \\
\text { medium freedom }\end{array}$ & \\
\hline & & 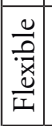 & $\begin{array}{l}\text { Possibility of choosing } \\
\text { a topic from the proposals } \\
\text { in IB }\end{array}$ & $\begin{array}{l}\text { High support / little } \\
\text { freedom }\end{array}$ & \\
\hline & & \begin{tabular}{|l|}
$\frac{0}{a}$ \\
$\frac{a}{x}$ \\
$\frac{0}{I I}$
\end{tabular} & $\begin{array}{l}\text { Obligation to } \\
\text { the prescribed to } \\
\text { ing to their defi }\end{array}$ & $\begin{array}{l}\text { High support / little } \\
\text { freedom }\end{array}$ & \\
\hline \multirow{4}{*}{ 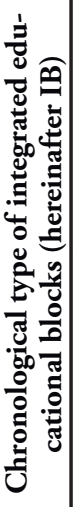 } & \multirow{2}{*}{$\begin{array}{l}\text { They are implemented } \\
\text { in a row; the blocks } \\
\text { correspond to the } \\
\text { seasons }\end{array}$} & 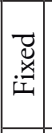 & $\begin{array}{c}\text { Suggestions for your own } \\
\text { topics }\end{array}$ & $\begin{array}{l}\text { Low support / high } \\
\text { freedom }\end{array}$ & \multirow{4}{*}{ 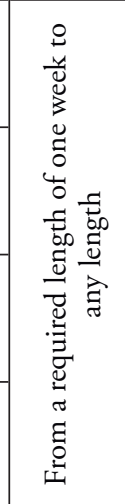 } \\
\hline & & 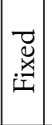 & $\begin{array}{l}\text { Possibility of choosing } \\
\text { a topic, or designing your } \\
\text { own }\end{array}$ & $\begin{array}{l}\text { Medium support / } \\
\text { medium freedom }\end{array}$ & \\
\hline & \multirow{2}{*}{$\begin{array}{l}\text { They are realised in a } \\
\text { row; the blocks cor- } \\
\text { respond to the months }\end{array}$} & 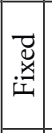 & $\begin{array}{l}\text { Possibility of choosing top- } \\
\text { ics from proposals in IB }\end{array}$ & $\begin{array}{l}\text { High support / little } \\
\text { freedom }\end{array}$ & \\
\hline & & 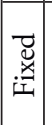 & $\begin{array}{l}\text { Obligation to implement } \\
\text { the prescribed topic in IB }\end{array}$ & $\begin{array}{l}\text { High support / little } \\
\text { freedom }\end{array}$ & \\
\hline 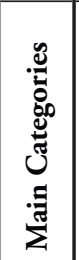 & 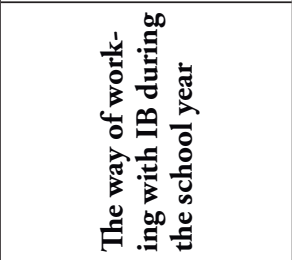 & 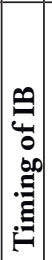 & 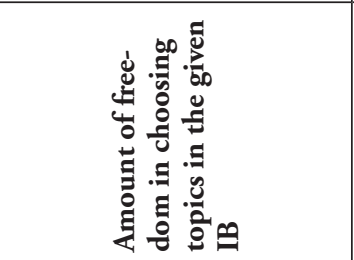 & 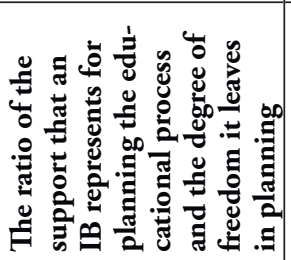 & 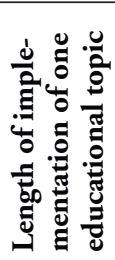 \\
\hline
\end{tabular}




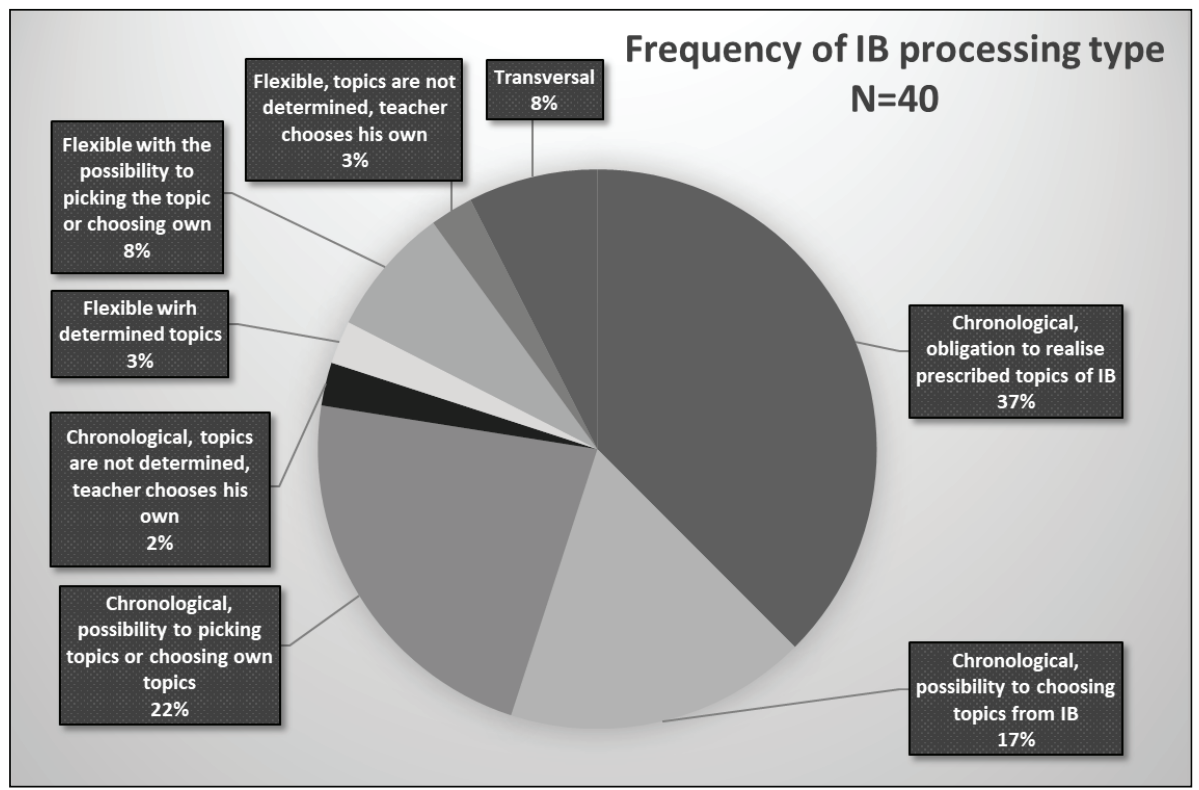

Figure 1 Frequency of school educational programmes according to main type of IB

\section{Intentions in IBs of school educational programmes}

After reviewing the selected SCHEPs, we realised that some IBs are not always constructed with educational goals. Some IBs contained a description of the educational content or offer of educational activities instead of defining the educational targets (intention) for the given thematic area (Figure 2).

The intentions of all the SCHEPs within the research sample were categorised according to whether they relate to the cognitive development, skills, or affective domain of children. The table below shows the distribution of their frequency.
The results showed that the educational intentions relate to facts which are close to the child's life within the natural and human world (Figure 3). In the set of identified intentions (see Figure 2), a cognitive focus predominates (47\%), then the affective focus (32\%), and the smallest number of intentions focused on skills development (21\%) (Table 5).

\section{Topics in IBs of school educational programmes}

The SCHEPs that were researched showed various topics in IBs (Table 6). In the content analysis, we focused on the composition and concept of topics. 
Figure 2 Intentions included in educational topics in IBs of school educational programmes

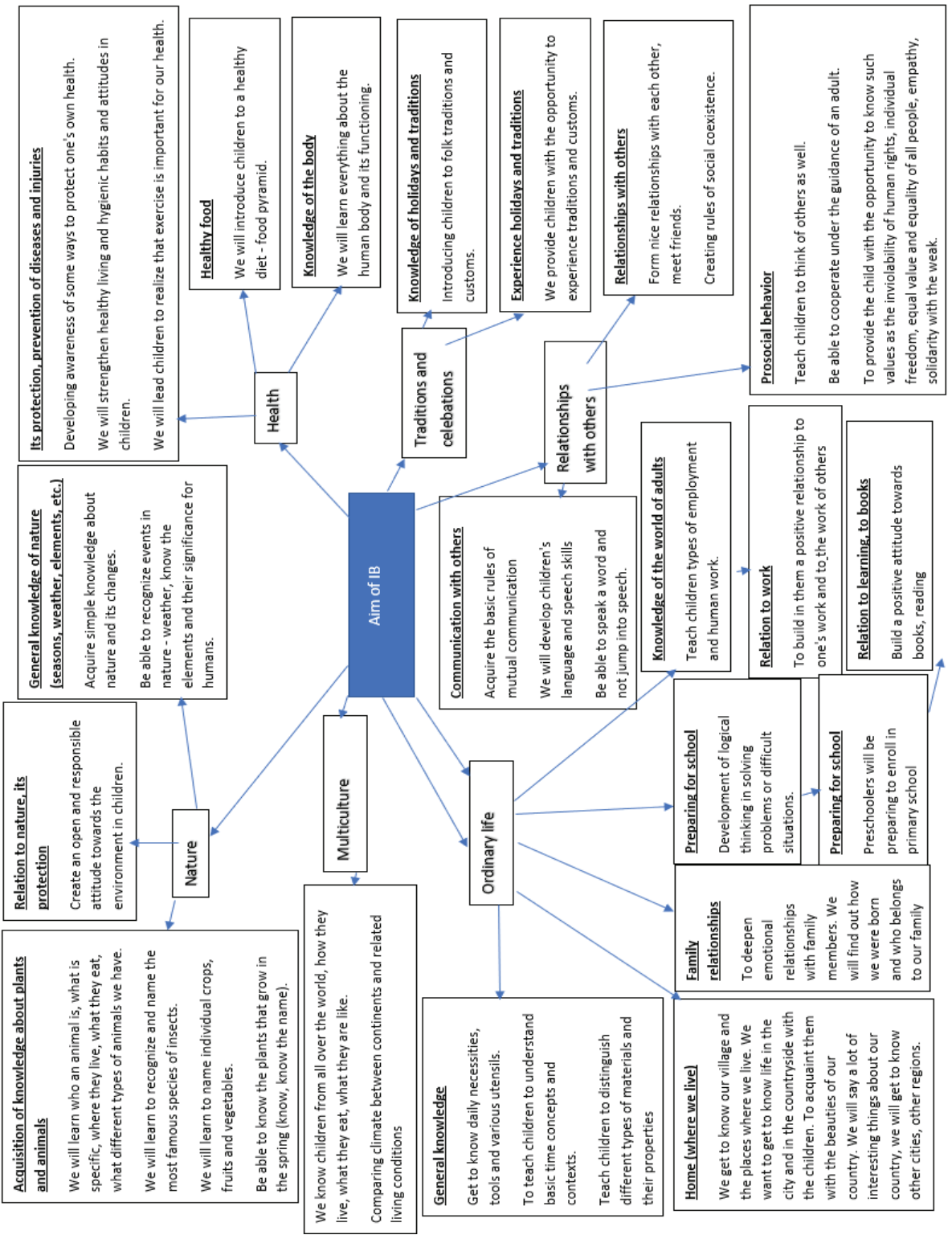




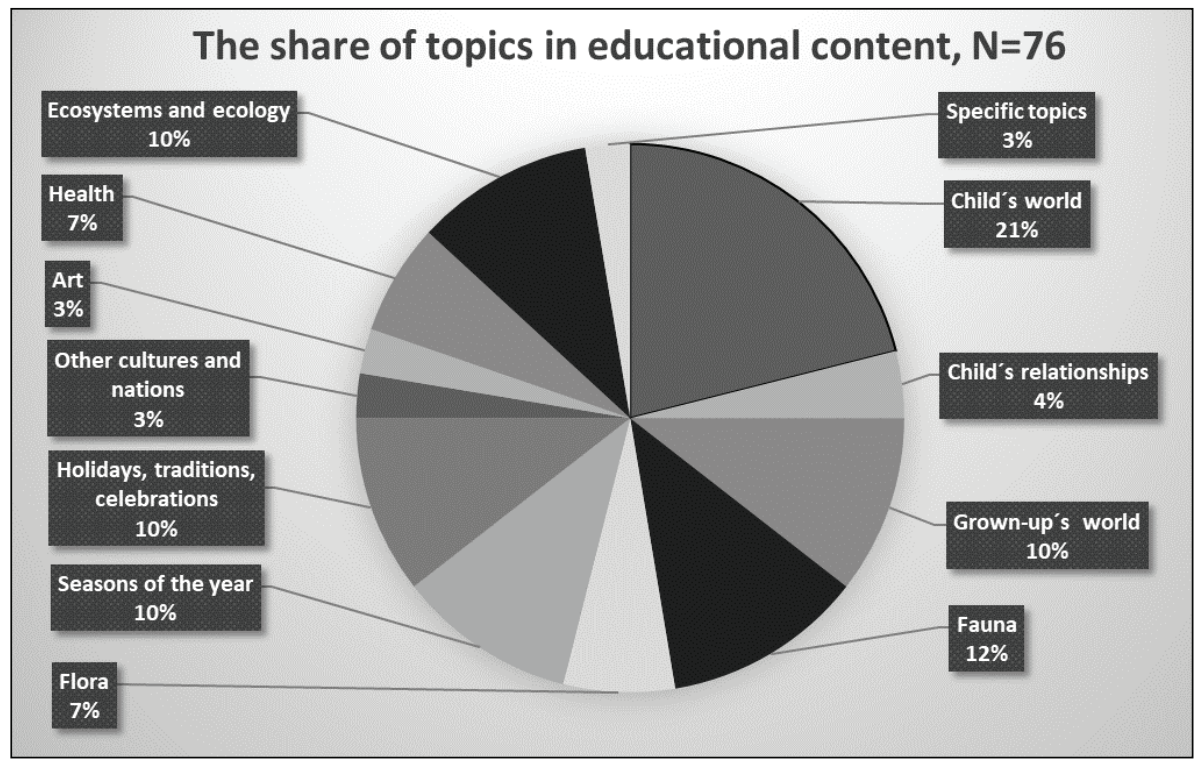

Figure 3 Proportion of representation of individual categories of topics listed in the IBs of SCHEPs

The content analysis revealed that the educational topics included in the IBs are based on the traditional perception of the cycle of seasons and traditional holidays. However, because of climate change, some of these topics are losing their meaning, such as "Snow Duvet
Time", or they are irrelevant to today's children, such as "Spring has come to the village" in urban kindergartens. The SCHEPs that were reviewed usually agreed on the distribution of educational topics listed in the IBs during the school year (in the period of autumn,

Table 5 Frequency of intentions of IBs in SCHEPs

\begin{tabular}{|l|c|c|}
\hline & $\begin{array}{c}\text { Frequency of occurrence } \\
\text { of the type of intentions in } \\
\text { IBs in SCHEPs (N=288) }\end{array}$ & $\begin{array}{c}\text { Proportion of occurrence of the } \\
\text { type of plans in IBs in SCHEPs }\end{array}$ \\
\hline $\begin{array}{l}\text { Cognitive area (know, name, } \\
\text { understand) }\end{array}$ & 134 & $47 \%$ \\
\hline $\begin{array}{l}\text { Skills area (be able to use, } \\
\text { manage) }\end{array}$ & 61 & $21 \%$ \\
\hline $\begin{array}{l}\text { Affective area (arouse interest, } \\
\text { have a desire to discover) }\end{array}$ & 93 & $32 \%$ \\
\hline
\end{tabular}


Table 6 Codes for the educational topics listed in IBs

\begin{tabular}{|c|c|c|c|}
\hline Autumn & Winter & Spring & Summer \\
\hline $\begin{array}{c}\text { Adaptation, } \\
\text { acquaintance with } \\
\text { kindergarten } \\
\text { Kindergarten friends } \\
\text { My day } \\
\text { The place where I live } \\
\text { Housing } \\
\text { City and village } \\
\text { Home, family } \\
\text { Autumn (characters) } \\
\text { Fruit/vegetables; field/ } \\
\text { garden } \\
\text { Autumn colours } \\
\text { Weather } \\
\text { Flying a kite } \\
\text { Halloween } \\
\text { Departure of birds } \\
\text { In the forest } \\
\text { Deciduous and } \\
\text { coniferous trees } \\
\text { Forest animals } \\
\text { Mushrooms, plants in } \\
\text { the forest } \\
\text { Preparing animals } \\
\text { for winter, animals in } \\
\text { winter }\end{array}$ & $\begin{array}{c}\text { Saint Nicholas } \\
\text { Christmas, Advent } \\
\text { New Year, Three Kings } \\
\text { Season } \\
\text { Winter (characters) } \\
\text { Snow, snowmen } \\
\text { Winter sports, } \\
\text { Olympics } \\
\text { Clothes } \\
\text { Eskimos } \\
\text { Fairy tales } \\
\text { Books } \\
\text { Objects around us } \\
\text { Word games } \\
\text { Labels } \\
\text { Music } \\
\text { Little artists } \\
\text { Carnival } \\
\text { Diseases, germs } \\
\text { At the doctor's } \\
\text { Human body, hygiene } \\
\text { I'm a boy, I'm a girl } \\
\text { Healthy food }\end{array}$ & $\begin{array}{l}\text { Advent of spring, spring } \\
\text { (characters) } \\
\text { Spring flowers, } \\
\text { meadows } \\
\text { In the garden } \\
\text { Insects } \\
\text { Easter } \\
\text { Witches } \\
\text { Chicks } \\
\text { Pets } \\
\text { Wildlife } \\
\text { On the road, traffic } \\
\text { Emergency units } \\
\text { Colours } \\
\text { Water in nature } \\
\text { Elements } \\
\text { Near a pond } \\
\text { Earth Day, our planet } \\
\text { Sorting waste } \\
\text { Mother's Day }\end{array}$ & $\begin{array}{c}\text { Professions } \\
\text { Crafts } \\
\text { Trips } \\
\text { Toys } \\
\text { Children's games } \\
\text { Children's Day } \\
\text { Summer } \\
\text { Summer sports } \\
\text { Holidays } \\
\text { The school is calling } \\
\text { By the sea } \\
\text { At the zoo } \\
\text { The world, continents } \\
\text { The universe } \\
\text { The Czech Republic } \\
\text { The road to prehistory } \\
\text { Preparation of the } \\
\text { performance for parents }\end{array}$ \\
\hline
\end{tabular}

winter, and spring). On the other hand, in the summer months the classification varied considerably and attractive topics arising from the interests of today's children (e.g. prehistory, space, continents) or newer topics (e.g. ecology) were included.

A total of nine kindergartens listed in their SCHEPs that they required weekly topics for the whole year - which is in conflict with the principles of creating educational content in pre-schools (e.g. Smolíková, 2006).

\section{Evaluative opinions of students on the design of IBs in SCHEPs}

The SCHEPs and written reflections of the students were paired together so that a pair of documents comes from a student who works in a pre-school.

The content analysis of the students' reflective reports found that they are satisfied with the amount of required content within IBs, which inspires them and gives them the freedom to choose a topic ( $\mathrm{Ta}$ ble 7). Designing broad topics themselves 
Table 7 Categories of evaluative opinions of students on the concept of IB within the SCHEP

\begin{tabular}{|c|c|c|c|c|c|c|c|c|c|}
\hline $\begin{array}{c}\text { Integrated } \\
\text { block }\end{array}$ & \multicolumn{4}{|c|}{ Chronological } & \multicolumn{4}{|c|}{ Flexible } & Trans- \\
\hline 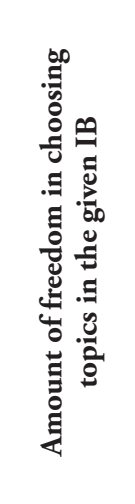 & 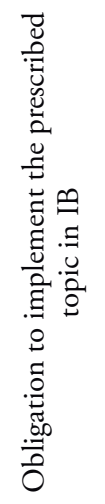 & 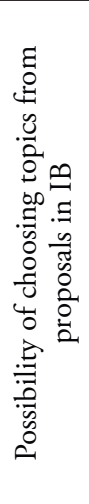 & 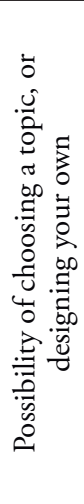 & 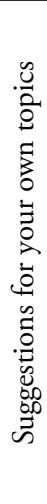 & 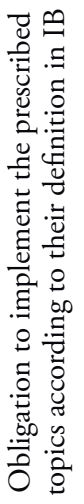 & 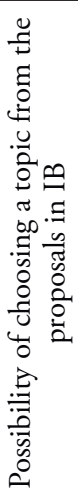 & 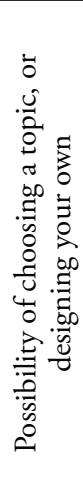 & 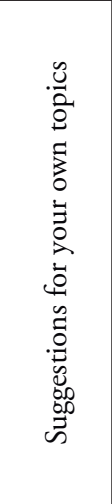 & 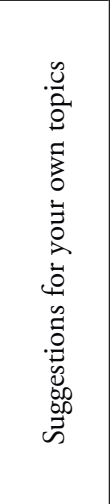 \\
\hline$\frac{8}{:}$ & 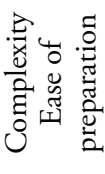 & 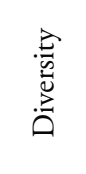 & 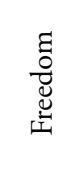 & 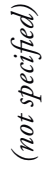 & 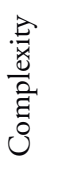 & 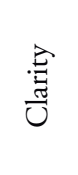 & 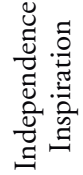 & 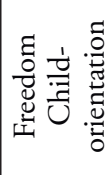 & 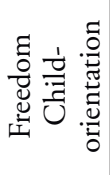 \\
\hline Z & 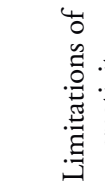 & 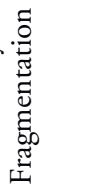 & 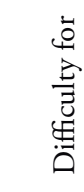 & & 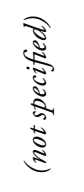 & & & 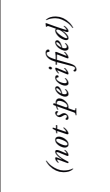 & 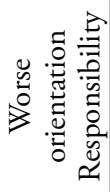 \\
\hline
\end{tabular}

has been criticised for its difficulty, but on the other hand highlighted as the best way to respect the needs and interests of the children in the pre-school. Designing narrow topics was evaluated positively because they are clear and systematic and simplify the planning of teaching and learning on the part of the teacher, but on the other hand it was criticised by some as restrictive. From the reflective reports of the students, we cite the following opin- ions as examples. "Flexible integrated blocks suit me because I try to plan according to the observed interests and needs of the children in the class." "It suits me to work differently every year." "Although we had a chronological arrangement of IBs, we had quite a lot of freedom in what we would do in the given IB and it was just about proving our abilities and skills during observations. "In the reflective reports, the students explained why the chronological arrangement suits them: 
- Clarity - "I like it when everything goes gradually; it's clearer than when you have to look for something in a haystack."

- Adherence to the sequence when planning educational activities - "Because the preparations are systematic and the principle of learning is taken into account, from the simplest to the most complex, the phases of the curriculum follow each other; it is not passed on chaotically."

- Easier planning - "In truth, it's easier to plan." "I can plan my preparation for classes a few weeks in advance."

- Respecting the natural course of the year and traditional holidays - "In our country, integrated blocks are processed according to changes in the world of nature. Therefore, this method cannot be considered flexible. It suits me, because the materials and stimuli for activities are given to us by nature; it stimulates the children's natural desire to discover and merges with our vision."

$5 \%$ of the Czech student teachers mentioned in their reflective reports that they had the opportunity to work according to the chronological and flexible approach of designing IBs for SCHEPs. On the basis of this experience, they all stated that they were satisfied with a flexible approach because it meets the requirement for planning based on the needs and interests of the child. One student wrote this as follows: "The chronological arrangement is probably clearer and easier as preparation and orientation and within the current school and calendar year for children and teachers, but the flexible concept gives a greater opportunity for freedom and expression to engage children in activities."
According to $15 \%$ of the Czech student teachers, specific topics in IBs are important for the planning of educational activities and in their reflective reports, they gave reasons for this. In the content analysis process, they were grouped into two categories:

- Inspiration - the teacher has a better idea of what could be done with the children, which was commented on as an advantage for less experienced teachers. In this case, the teacher wants to be inspired by individual topics, but demands the freedom to choose her own topic: "We have a sufficient number of IBs, where each class can choose from several topics. The choice of topics is up to the free will of every teacher."

- Simplification - the teacher has simplified planning based on a sufficient offer of specific topics. According to one teacher, this gives the opportunity "to make the SCHEP a functional tool even for less experienced teachers".

\section{RESULTS OF THE QUESTIONNAIRE SURVEY}

\section{Approach of IB in SCHEP and preferences of respondents}

Tables 8 and 9 show the results of the respondents' answers to two questions. The first looked at the designing of IBs in school educational programmes in the pre-schools where the student teachers work. The second question then examined which type of IB the student teachers prefer. 
Table 8 Types of designing of IBs in the SCHEP according to the experiences of respondents

\begin{tabular}{|l|c|c|c|c|}
\hline \multirow{2}{*}{$\begin{array}{l}\text { In the pre-school where } \\
\text { I work, the IBs in the } \\
\text { SCHEP are processed: }\end{array}$} & \multicolumn{2}{|c|}{$\begin{array}{c}\text { Students of the research group } \\
\text { from FE UK (N=65) }\end{array}$} & \multicolumn{2}{|c|}{$\begin{array}{c}\text { Students of the research group } \\
\text { from FE UMB (N=56) }\end{array}$} \\
\cline { 2 - 5 } & Frequency & Expression (\%) & Frequency & Expression (\%) \\
\hline chronologically & 33 & 51 & 12 & 22 \\
\hline flexibly & 26 & 40 & 18 & 32 \\
\hline $\begin{array}{l}\text { I do not currently work } \\
\text { in a pre-school }\end{array}$ & 5 & 8 & 17 & 30 \\
\hline otherwise & $1^{*}$ & 1 & 9 & 16 \\
\hline Together & 65 & 100 & 56 & 100 \\
\hline
\end{tabular}

* The respondent stated that in the pre-school where she works, she had the chance to get acquainted with the SCHEP.

Table 9 Types of designing of IBs in the SCHEP, according to the preferences of the respondents

\begin{tabular}{|l|c|c|c|c|}
\hline \multirow{2}{*}{$\begin{array}{l}\text { It suits me when the inte- } \\
\text { grated educational blocks } \\
\text { in school educational } \\
\text { programmes are processed: }\end{array}$} & $\begin{array}{c}\text { Students of the research group } \\
\text { from FE UK }(\mathbf{N}=\mathbf{6 5})\end{array}$ & $\begin{array}{c}\text { Students of the research group } \\
\text { from FE UMB (N=56) }\end{array}$ \\
\cline { 2 - 5 } & Frequency & Expression (\%) & Frequency & Expression (\%) \\
\hline chronologically & 31 & 48 & 18 & 32 \\
\hline flexibly & 34 & 52 & 29 & 52 \\
\hline otherwise & - & - & 9 & 16 \\
\hline together & 65 & 100 & 56 & 100 \\
\hline
\end{tabular}

The questionnaire survey of the student teachers' opinions resulted in findings suggesting that they prefer the concept of planning IBs according to their experience. While the Czech respondents mostly worked in pre-schools, where the IBs in the SCHEP were arranged chronologically (51\%), among the Slovak respondents, SCHEPs with a flexible concept of IBs were most popular (32\%) (Table 8). When we compare the experience of how it works in practice in this area, and how it should work in the opinion of the respondents (Tables 8 and 9), we find that the flexible type of IB is preferred by more than half of the Czech and Slovak respondents. The chronological type (Table 9) suits the Czech respondents more (48\%) than it does the Slovak respondents (32\%).

\section{Ways of choosing topics in SCHEPs and preferences of re- spondents' opinions with regard to the planning of educational activities in the classroom}

The results below show the differences between the reality of pedagogical practice and the preferences of the Czech and Slovak students. 
Table 10 The method of choice of topics in the SCHEP for classroom planning of educational activities implemented in the pre-school of the respondents

\begin{tabular}{|l|c|c|c|c|}
\hline \multirow{2}{*}{ In the pre-school where I work: } & \multicolumn{2}{|c|}{$\begin{array}{c}\text { Students of the research } \\
\text { group from FE UK } \\
(\mathbf{N = 6 5})\end{array}$} & \multicolumn{2}{c|}{$\begin{array}{c}\text { Students of the research } \\
\text { group from FE UMB } \\
\text { (N=56) }\end{array}$} \\
\cline { 2 - 5 } & Frequency & Expression (\%) & Frequency & Expression (\%) \\
\hline $\begin{array}{l}\text { we have given topics in the } \\
\text { SCHEP for our weekly teaching }\end{array}$ & 12 & 19 & 24 & 43 \\
\hline $\begin{array}{l}\text { we have indicated recommended } \\
\text { topics of teaching in the SCHEP } \\
\text { from which we choose }\end{array}$ & 7 & 11 & 1 & 2 \\
\hline $\begin{array}{l}\text { we have indicated recommended } \\
\text { topics of teaching in the SCHEP; } \\
\text { we choose from them, and we can } \\
\text { also add our own }\end{array}$ & 20 & 31 & 13 & 23 \\
\hline $\begin{array}{l}\text { I choose the topic of teaching } \\
\text { myself, only on the basis of an IB }\end{array}$ & 21 & 32 & 1 & 2 \\
\hline $\begin{array}{l}\text { I do not currently work in } \\
\text { a kindergarten }\end{array}$ & 5 & 7 & 17 & 30 \\
\hline \begin{tabular}{l} 
Together \\
\hline
\end{tabular} & 65 & 100 & 56 & 100 \\
\hline
\end{tabular}

Table 11 Methods for choosing topics in the SCHEP for class planning of educational activities in pre-schools which are preferred by the respondents

\begin{tabular}{|l|c|c|c|c|}
\hline \multirow{2}{*}{ It suits me when: } & \multicolumn{2}{|c|}{$\begin{array}{c}\text { Students of the } \\
\text { research group from } \\
\text { FE UK (N=65) }\end{array}$} & $\begin{array}{c}\text { Students of the } \\
\text { research group from } \\
\text { FE UMB (N=56) }\end{array}$ \\
\cline { 2 - 5 } & Frequency & $\begin{array}{c}\text { Expres- } \\
\text { sion (\%) }\end{array}$ & Frequency & $\begin{array}{c}\text { Expres- } \\
\text { sion (\%) }\end{array}$ \\
\hline $\begin{array}{l}\text { we have given topics in the SCHEP for our } \\
\text { weekly teaching }\end{array}$ & 4 & 6 & 24 & 43 \\
\hline $\begin{array}{l}\text { we have indicated recommended topics of } \\
\text { teaching in the SCHEP from which we choose }\end{array}$ & 3 & 5 & 7 & 12 \\
\hline $\begin{array}{l}\text { we have indicated recommended topics of } \\
\text { teaching in the SCHEP; we choose from them, } \\
\text { and we can also add our own }\end{array}$ & 42 & 65 & 19 & 34 \\
\hline $\begin{array}{l}\text { I choose the topic of teaching myself, only on } \\
\text { the basis of an IB }\end{array}$ & 16 & 25 & 6 & 11 \\
\hline Together & 65 & 100 & 56 & 100 \\
\hline
\end{tabular}


The Slovak respondents (43\%) had experience with weekly topics in the preschool curricula. They also agreed with this approach to planning topics (43\%); however, $30 \%$ of them did not currently work in a pre-school. The Czech respondents $(32 \%)$ who currently worked mainly in pre-schools (93\%) had the most experience $(32 \%)$ with the free choice of topics in accordance with IBs (Table 10). If the Czech respondents could decide how it should be, they would prefer to choose from the recommended topics with the addition of their own (65\%; Table 11). The Slovak respondents (34\%) are not much different in this area. The Czech respondents, unlike the Slovak respondents, only minimally prefer weekly topics $(6 \%$; Table 11). One respondent explained her choice as follows: "The recommended topics come to me as a very helpful element of the school educational programme. It is not necessary to stick to them, and yet the teacher can use them easily if no suitable alternative can be found. Furthermore, she can mark on them what she used in what years, and so she does not repeat the same thing over and over every year. I also see the advantage of auxiliary topics as easier orientation and adaptation for a new teacher, whether a beginner or an experienced one, who comes to a pre-school and does not have to guess from the beginning what topics the pre-school tends to prefer."

The answers of the Czech respondents also included the belief that instead of the topics mentioned in the SCHEPs, it is more important to state educational goals and their interconnection. "I think that the topic can be arbitrary, according to the children's interest, according to the teacher's taste; most often, when choosing a topic, we are based on natural phenomena, current events, stories, and fairy tales. Personally, I can't imagine that the topics would be strictly given as a requirement (...) What is more important, in my opinion, is the content of the curriculum, and it should flow from one to the next. I think that the content of the curriculum in a kindergarten can be incorporated into almost any topic." This answer of the respondent is an example of understanding the planning of topics of topics according to the concept of a transversal approach.

However, in other options for working with topics in the SCHEP, more flexible ways of working with thematic planning occur in practice, allowing teachers to select and add topics, but also freely create a complete thematic orientation of weekly (or longer) plans.

A quarter of the Czech respondents were in favour of complete freedom in the choice of topics and the length of their implementation, which is not an insignificant number; moreover, this method clearly supports the planning of teaching and learning based on the assessment of children's learning.

\section{Opinions about the length of time for a topic of planned educational activities for a class}

In both groups of respondents, the most popular period for one topic was one week (35\% Czech, 43\% Slovak, Table 12). 
$35 \%$ of the Czech respondents also commented favourably on extending the topic for various lengths of time when it supported the children's educational needs. On the other hand, only 16\% of the Slovak respondents commented favourably on extending topics for longer periods of time. The respondents pointed to the fact that planning with weekly topics leads to fragmentation of the educational offer, superficiality, and disrespect for children's current interests. "Weekly plans guide us to discuss one topic, but this lacks the connection between other topics that relate to one whole, such as the whole of autumn. Sometimes there is also no time to get everything done properly in one week, and since the next week is already a new topic, there is no room to finish the old topic."

The reason for including topics for the week was the insufficient cooperation of teachers in one class or the alternating of their shifts, when the effort is probably to ensure that children do not lose any part of the topic during a longer implementation period. "I would like to work on some topics for a longer period of time, because some of them are more extensive and I do not have time; unfortunately, my colleague in the class does not agree with this, so we only have topics for one week, which gives me little time for some topics." "I see a problem in the fact that my colleague and I take turns after a week, and everyone is actually "in charge" on their own. Everyone has a different way of understanding the topic."

\section{Discussion}

\section{Planning IBs in SCHEPs as a basis for classroom educational activities (Questions 1, 4, and 5)}

The content analysis of the planning of IBs in SCHEPs resulted in their division into three basic types. These types were based upon the usability of topics by teachers for planning classroom educational

Table 12 Opinions about the length of time for a topic of planned educational activities for a class.

\begin{tabular}{|l|c|c|c|c|}
\hline \multirow{2}{*}{$\begin{array}{l}\text { When planning educational } \\
\text { activities, I prefer the class to } \\
\text { work on topics or projects for: }\end{array}$} & \multicolumn{2}{|c|}{$\begin{array}{c}\text { Students of the research } \\
\text { group from FE UK (N=65) }\end{array}$} & \multicolumn{2}{c|}{$\begin{array}{c}\text { Students of the research } \\
\text { group from FE UMB (N=56) }\end{array}$} \\
\cline { 2 - 5 } & Frequency & Expression (\%) & Frequency & Expression (\%) \\
\hline 1 week & 23 & 35 & 24 & 43 \\
\hline 2 weeks & 7 & 11 & 2 & 4 \\
\hline 2 weeks to a month & 11 & 17 & 4 & 7 \\
\hline a longer period & 1 & - & - & - \\
\hline $\begin{array}{l}\text { as needed for different long } \\
\text { periods }\end{array}$ & 23 & 35 & 9 & 30 \\
\hline $\begin{array}{l}\text { I do not currently work in } \\
\text { a pre-school }\end{array}$ & - & - & 17 & 100 \\
\hline Together & 65 & 100 & 56 & 30 \\
\hline
\end{tabular}


activities (see Figure 1). We also searched for a suitable terminology for the types we identified. On the basis of the content categories (see Table 4), we proposed the terms chronological, elective, and transversal types of IBs in SCHEPs. It is typical of the chronological type that the IBs are arranged in time according to the seasons and months, for gradual implementation during the school year. We identified and chose the elective type of IB on the basis of the terminology used in our questionnaire survey. It turned out that the term flexible, which was used in the questionnaire, was ambiguous for the respondents. A certain degree of flexibility was also found in the chronological type and at the same time is a characteristic feature of the transversal type. For this reason, we propose the term "elective", as it does not have significant overlaps within the definition of other characteristics of the curriculum. Although the IBs as a whole are fixed in the SCHEPs, teachers can choose their order during the school year. With the chronological and elective types of IBs, there are still nuances, given the extent to which the content of these blocks is a requirement for teachers in terms of the topics offered. In addition, this is also influenced by the extent to which teachers can include their own topics and content based on the current situation in the pre-school, the class, and children's interests. The transversal type of IB allows teachers to choose intentions, topics, and educational offers across IBs and to interweave them. Transversal IBs are not usually oriented according to the seasons, but the IBs define individual areas that are not time-limited.

With a chronological and elective type of IB, the degree of commitment/freedom ranged from the absolutely essential nature of the topics, the ability to choose from the proposed topics, and the ability to choose from the proposed topics and add personally chosen topics, to freedom in choosing the topic and the length of its implementation in the educational process. In the case of the transversal type, this freedom results from the very essence of the way in which the class educational programme is designed (see Table 7).

\section{Intentions and topics in IBs of \\ SCHEPs (Questions 2, 3, and 6)}

The results showed that the educational intentions meet the requirements of the SCHEP in relation to the child's life. A cognitive focus predominates, with the fewest intentions being focused on the development of skills. According to the annual report of the Czech School Inspectorate from 2018, teachers in pre-school education focus equally on the development of knowledge (in $86 \%$ of cases) and skills (in $94.9 \%$ of cases), and less on the development of children's attitudes (in $66.3 \%$ of cases). This slight contradiction of the stated intentions may be due to the fact that monitoring the development of both skills and knowledge in pre-school children is a matter of course for teachers and is easier to assess. Affective goals are developed in the long term, so the degree of fulfilment is less easy to observe and record. 
The research found out that there were certain difficulties when formulating educational targets as a major part of IBs is orientated towards educational targets focusing on cognition and skills. These findings are in agreement with the longterm teaching experience of the authors, as these difficulties appear very often in less experienced teachers when entering pedagogical practice and concur with the findings of other authors (e.g. Syslová et al., 2019).

A surprising finding was the relatively high demand for, and satisfaction with, predefined topics. The qualitative analysis revealed that the respondents were divided into two basic groups. For one, it was crucial that education responds to the child's needs and interests, suggesting that a transversal or elective type of IB was best. The other group emphasised the need for systematic, thoughtful, and consecutive teaching, for which the chronological type seemed more appropriate. However, as one respondent stated, the transversal type of IB does not exclude the ability to follow a sequence of learning objectives, as this can be maintained in any topic. The only difference is in the high demands on the professional abilities of the teacher, which are higher when working with the elective type of IB than the chronological one. The certain "helplessness" of less experienced teachers and their desire for support in the form of topics is understandable, but it could stimulate consideration of how to further improve the training of future teachers with regard to pedagogical planning.

\section{Opinions about the length of time for a topic of planned educational activities for a class \\ (Question 7)}

We consider the clear preference for longer-term thematic (or topic) units very positive as this makes it easier to respond to children's educational needs and interests. However, the fact that more than a third of the respondents prefer the division of education into weekly units should not be overlooked. This fact may indicate a culture of viewing pre-school education as similar to 'school', with a need to gain as much knowledge as possible, without paying enough attention to the personal experiences of the child. The information can thus be conveyed in a transmissive manner and without interrelationship.

\section{ConClusion}

The literature in the field of educational planning discusses two possible approaches to the creation of integrated educational blocks, linear (chronological) and flexible. However, the research showed that in practice within the SCHEPs for pre-schools there are three main types of planning IBs applied in the SCHEPs that were reviewed. Because of the confusion and misunderstanding of the existing terminology, we therefore propose to refine it according to our findings. In addition to the chronological type, we propose to introduce the concept of an elective (giving teachers the possibility of implementing the proposed IBs at a chosen time) and 
a transversal type (the teacher selects goals and content from several IBs at once and creates a unique integrated educational block for the class).

An important finding of our research is the continuing influence of approaches to planning remaining from the time of standardised education before the early 1990s and which is reflected in the practice of fixed weekly and chronological planning, as well as systematic teaching of individual topics. FEP PE (2018) stipulates that the content of pre-school education should be based on the interests and needs of the children in the class, but our analysis showed that $40 \%$ of the school educational programmes in our research included specific integrated educational blocks (including topics and their order) as a school requirement for teachers. Among the school educational programmes that were reviewed, an approach prevails that may not be enough to enable the individualisation of pre-school education according to the needs and interests of children, which also coincides with the findings of the Czech School Inspectorate (CSI, 2020).
A comparison of the respondents' opinions showed that both countries face a similar problem. Although the socialcentred $^{1}$ approach to planning educational activities persists as a relic of times when there was standardised education, current students are not so influenced by such practice today. A child-centred view of education has changed their approach to planning educational activities, and we consider this to be indicative of a gradual and positive change from the established procedures of the past.

The discussion focused on the revision of the state curricula of pre-school education in the Czech and Slovak Republics, which could lead to clarification of ways to plan the educational content of school educational programmes and to actually pursue the goals of pre-school education as stated in the Czech FEP PE (2018) and the Slovak Education Act (2008). Both these documents emphasise an individual approach, as well as a personality-oriented model of pre-school education, free of schematism, a standardised approach, and centralisation.

\section{REFERENCES}

Burkovičová, R. (2008). Pedagogické projektováni a prezentace pedagogického projektu $v$ učitelství pro mateřské školy [Pedagogical design and presentation of a pedagogical project in kindergarten teaching]. $2^{\text {nd }}$ ed. University of Ostrava.

CSI. (2019). Kvalita a efektivita vzdèlávání a vzdèlávací soustavy ve školním roce 2018-2019 - Výročni zpráva [Quality and efficiency of education and the education system in the 2018-2019 school year - Annual report]. Praha: Czech School Inspectorate. Available from: www.csicr.cz

\footnotetext{
${ }^{1}$ The intentions of the „socio-centered“ approach are based on the interests of society and prioritize the needs of society instead of the needs and interests of the child. This model characterized the concept of pedagogical work in the countries of the former Eastern block before 1989.
} 
Education Act (2008). Zákon č. 245/2008 Z. z., o výchove a vzdelávani (školský zákon) a o zmene a doplneni niektorých zákonov [Act no. 245/2008 Coll. on upbringing and education (Education Act) and on amendments to certain acts]. Available from: www.slov-lex.sk

Education Act (2004). Zákon č. 561/2004 Sb., o predškolnim, základnim, střednim, vy̌šsím odborném a jiném vzdèláváni (školský zákon) [Act no. 561/2004 Coll. on preschool, basic, secondary, higher vocational and other education (Education Act)]. Available from: www. msmt.cz

FEP PE (2018). Rámcový vzdělávaci program pro předškolni vzdělávání [Framework educational programme for preschool education]. Praha: Ministry of Education, Youth and Sports. Available from: www.msmt.cz

Hajdúková, V. et al. 2009. Metodika na tvorbu školských vzdelávacích programov [Methodology for creating school educational programmes]. Bratislava: Ministry of Education, Science, Research and Sport. Available from: www.minedu.sk

Krejčová, V., Kargerová, J., \& Syslová, Z. (2015). Individualizace v mateřské škole [Individualisation in kindergarten]. Praha: Portál.

Miles, M. B., \& Huberman, A. M. (1994). Qualitative data analysis: An expanded sourcebook. $2^{\text {nd }}$ ed. Los Angeles: SAGE.

Průcha, J. (2016). Předškolni ditě a svèt vzděláváni: prèhled teorie, praxe a výzkumných poznatkì [The preschool child and the world of education: An overview of theory, practice, and research findings]. Praha: Wolters Kluwer.

SEP (2016). Štátny vzdelávaci program pre predprimárne vzdelávanie v materských školách [State educational programme for pre-primary education in kindergartens]. (Online). Available from: www.statpedu.sk

Šmelová, E., \& Prášilová, M. (2018). Didaktika předškolniho vzdělávání [Didactics of preschool education]. Praha: Portál.

Smolíková, K. (2005). Manuál k př́pravè školniho (trídního) vzdèlávacího programu mateřské skoly [Manual for the preparation of the school (class) educational programme of the kindergarten]. Praha: Výzkumný ústav pedagogický.

Smolíková, K. (2006). Manuál k prípravě školniho (trídniho) vzdèlávacího programu mateřské skoly [Manual for the preparation of the school (class) educational programme of the kindergarten]. 2nd ed. Praha: Výzkumný ústav pedagogický.

Švař́ček, R., \& Šedová, K. (2014). Kvalitativní výzkum v pedagogických védách [Qualitative research in pedagogical sciences]. 2nd ed. Praha: Portál.

Svobodová, E. (2007). Obsah a formy prèšskolniho vzděláváni [Content and forms of preschool education]. University of South Bohemia in České Budějovice.

Svobodová, E. (2010). Vzděláváni v mateřrsé škole: Školni a trídni vzdèlávací program [Kindergarten education: School and classroom educational programme]. Praha: Portál.

Syslová, Z., Burkovičová, R., Kropáčková, J., Šilhánová, K., \& Štěpánková, L. (2019). Didaktika materské školy [Kindergarten didactics]. Praha: Wolters Kluwer. 


\section{Eva Koželuhová}

Department of Pre-primary and Primary Education, Faculty of Education, Charles University, Czech Republic; e-mail: eva.kozeluhova@pedf.cuni.cz

\section{Barbora Loudová Stralczynská}

Department of Pre-primary and Primary Education, Faculty of Education, Charles University, Czech Republic

\section{Milena Lipnická}

Department of Elementary and Preschool Education, Faculty of Education, Matej Bel University,

Slovak Republic

\section{KOŽELUHOVÁ, E., LOUDOVÁ STRALCZYNSKÁ, B., LIPNICKÁ, M. Plánování vzdělávacího obsahu ve školních kurikulárních dokumen- tech: př́klady současné praxe $\mathrm{v}$ mateřských školách $\mathrm{v}$ České republice a na Slovensku}

Cílem výzkumu bylo analyzovat zpiosoby, jakými jsou v České republice a na Slovensku plánovány a realizovány vzdèlávaci obsahy na úrovni jednotlivých mateřských škol. Výzkum sledoval, jaká jsou zařazovaná vzdělávaci témata, jaké jsou sledovány vzdělávaci cíle a jaké rüzné prìstupy se uplatňuji prì tvorbè školnich vzdèlávacích programů.

Proni část výzkumu sestávala z kvalitativni obsahové analyzy školnich vzdèlávacích programů 40 mateřských škol v České republice a 40 reflektivních zpráv učitelù tèchto mateřských škol. Vyzkum zjištoval prístupy mateřských škol k tvorbè integrovaných blokì a preference učitelu prì implementaci těchto integrovaných blokù do pedagogické praxe. Druhá část výzkumu byla realizována ve spolupráci s Pedagogickou fakultou Univerzity Mateja Bela v Banské Bystrici. Vyzkumná data byla ziskána pomoci dotaznikového šetreni mezi studenty kombinované formy studijnich programů zamèrených na připravu budoucich učiteli mateŕských škol.

Vysledky z výzkumného vzorku ukazuji, že mezi respondenty $v$ obou zemích je nejvice preferováno chronologické razeni integrovaných blokü. Mateřské školy navrhovaly vzdèlávaci obsah $v$ souladu s ročnim obdobim a strukturovaly ho do týdennich témat. Tento zpuisob nemusi naplñovat požadavek českého ani slovenského kurikula, aby vzdělávaci obsah vycházel z aktuálních potřeb a zájmù dètí. Ačkoli někteři učitelé mèli možnost si volit svá vlastni témata, od vètšiny učitelù se stále očekává, že budou realizovat témata uvedená ve školnich vzdèlávacich programech. $V$ závèru príspèvek prináši možné vysvètleni této situace a podněty pro dalši rozvoj.

Klíčová slova: predškolni vzdèlávaci obsah, školni vzdèlávací program, kurikulum, plánováni 